\title{
Grazing influences on watering point vegetation in the Chihuahuan desert
}

\author{
MICHAEL FUSCO, JERRY HOLECHEK, ACKIM TEMBO, ALPIAYOU DANIEL, AND \\ MANUEL CARDENAS
}

Authors are graduate research assistant, professor and graduate research assistants, Dept. of Animal and Range Sciences, New Mexica State Univ., Las Cruces, 88003; and professor, Dept. of Exp. Stat., New Mexico State Univ., Las Cruces, 88003.

\begin{abstract}
Long-term influences of livestock grazing on vegetation around watering points was studied on 2 upland Chihuahuan desert ranges in southcentral New Mexico using regression analysis. One range had been conservatively stocked since the 1950's while the other was more heavily stocked. About $45 \%$ of the climax vegetation occurred on the heavily stocked range compared to $70 \%$ on the conservatively stocked range. During 3 years of study, both ranges were stocked conservatively so annual utilization of the key forage grasses was $30-35 \%$. Regression analyses showed black grama (Boueteloua eriopoda Torr.), mesa dropseed (Sporobolus flexuosus Thurb, Rybd.), threeawn (Aristida sp.), and total perennial grass standing crop increased as distance from water increased on the good condition range $(P<0.05)$. However, black grama and threeawn standing crop showed no association with distance from water on the fair condition range. Broom snakeweed (Xanthocephalum sarothrae Pursh.), the primary poisonous plant found on both ranges, was associated $\left(r^{2}=\right.$ 0.35) with distance from water only on the good condition range in April. Poisonous plants other than broom snakeweed decreased as distance from water increased with the exception of the fair condition range in October. No livestock losses from poisonous plants were noted on either range over the 3 years. We attribute this to the present conservative stocking rates. Our study supports the recommendation that downward stocking rate adjustments be made for the zone more than $1,600 \mathrm{~m}$ from water.
\end{abstract}

Key Words: rangeland, grazing management, forage, stocking rate, range condition

Livestock use forage plants more heavily around watering points compared to areas away from water (Valentine 1947, Holscher and Woolfolk 1953, Pinchak et al. 1991, Hart et al. 1991, 1993). However research documenting the long-term (over 30 years) interactions of livestock grazing and distance from water on forage productivity is lacking. This type of information

\footnotetext{
This research was supported by the New Mexico Agr. Exp. Sta., Las Cruces, 88003 , and was part of project 1-5-274174.

This manuscript was accepted 7 Jun. 1994.
}

would be useful in refining adjustments for distance from water in grazing capacity determinations, and in decisions regarding location and spacing of watering points. There is still reluctance for managers in government agencies and on private ranches to adjust stocking rates for distance from water and slope.

This study was designed to evaluate vegetation standing crop biomass and species composition at varying distances from water on 2 upland sandy ranges in different ecological condition in the Chihuahuan desert of southcentral New Mexico, with known grazing histories. The hypothesis tested was that after decades of livestock grazing production of desirable forage increased more rapidly on range in good condition than on range in fair condition as distance from water increased.

\section{Study Area}

The 2 study ranges are located $37 \mathrm{~km}$ north of Las Cruces, N.M. Their western boundaries are adjacent to Interstate Highway 25. The study area is on the southern end of the Jornada Del Muerte Basin. This area is bounded by the San Andres Mountains on the east and several isolated mountains on the west. Elevation varies from 1,188 to $1,371 \mathrm{~m}$ with level or gently rolling hills. There are no permanent streams.

The basin consists of unconsolidated Pleistocene detritus. This alluvial fill from the bordering mountains is as much as $100 \mathrm{~m}$ thick and the filling process is still active. Coarser sediments are found near the foothills with finer soil particles in the drainages. The soils show almost no organic matter and little change in texture between surface and subsurface layers. The lime content is high in all of the soil types, grading into a solid, calcareous substrata at variable depths in the coarser soils.

Study pasture soils are primarily shallow, fine sandy loams of the Simona-Cruces associations (fine loamy, mixed, thermic, typic Haplargids). The topography is relatively flat with all slopes under $5 \%$.

The climate of the Jornada basin is typical of arid grassland regions. There is an abundance of sunshine, a wide range between day and night temperatures throughout the year, low relative humidity and low, extremely variable precipitation.

Seasonal patterns of precipitation are characterized by small amounts in spring and a peak in August with gradually reduced amounts during fall (Pieper and Herbel 1982). A smaller peak 
occurs in January. Summer precipitation originates in the Gulf of Mexico and occurs as intense local convectional thunderstorms of short duration. Winter precipitation originates from the Pacific Ocean and is characterized by gentle frontal storms.

Temperatures reach a peak in June and decline until December. Wind velocities are highest in March, April, and May and lowest in December. These winds cause much soil erosion and increase water stress on vegetation by increasing transpiration and reducing the soil moisture content by evaporation.

During the study (1988-1990), precipitation on the experimental area was about $17 \%$ above the long-term average (Fusco 1993). There were no temperature aberrations.

Vegetation on the Jornada Basin is classified as Chihuahuan desert grassland and shrubland (Brown 1982). Most of the grassland areas have been invaded by brushy species during the last 100 years (Brown 1950, Dick-Peddie 1966). The principal grassland type is black grama (Bouteloua eriopoda Torr.) with mesa dropseed (Sporobolus flexuosus Thurb. Rybd.) intermixed. The shrub type is mainly honey mesquite (Prosopis glandulosa Torr.) sandhills, with snakeweed (Xanthocephalum spp.) invading certain sites. Annual forbs include leather leaf croton (Croton pottsii Lam.), nightshades (Solanum sp.), globemallow (Sphaeralcea sp.) and Russian thistle (Salsola iberica L.). The presence of these forbs is dependent on seasonal precipitation.

Much of the grazing history is based on interviews with retired employees of the Animal and Range Science Department at NMSU. Before 1922 when the College Experimental Ranch was established, both study areas were mostly black grama grassland with a minor brush component (honey mesquite). Although some of the area was heavily grazed by cattle, watering points were widely spaced which minimized the number of zones of degradation. During the 1930's and the 1940's, the College Ranch range was stocked conservatively compared to the adjacent BLM ranges. Reports from this period show the College Ranch range used in our study produced about $360 \mathrm{~kg}$ of perennial forage per ha and was stocked at about 40 ha animal unit ${ }^{-1}$ (Neale 1937 , Valentine 1947, Knox et al. 1959). Based on Valentine (1947), the utilization level on much of the College Ranch range averaged near $35 \%$. In contrast accounts by retired College Ranch personnel and BLM records indicate the adjacent BLM study range was stocked at around 24 ha animal unit ${ }^{1}$, and the utilization level averaged somewhere between 50 and $60 \%$.

Extended drought during the mid-1950's reduced the black grama on both study areas. Following the drought, honey mesquite increased on both ranges. These changes are documented on the adjoining Jornada Experimental Range by Buffington and Herbel (1965). From 1954 to 1967 period, range condition appears to have declined severely on the College Ranch because of combination of drought and failure to adequately adjust stocking rate.

In 1967, the College Ranch study area was placed under intensive grazing management and the stocking rate was reduced from 41 to 67 ha animal unit ${ }^{-1}$ (Beck 1978. Beck et al. 1987). Since then, utilization of the key forage species has averaged about 30 percent. The stocking rate has been increased from 67 ha per animal unit ${ }^{-1}$ to 45 ha per animal with no increase in degree of forage use or sacrifice in cattle performance (Beck et al. 1987, Beck and Kiesling 1991). Overall condition using the Soil Conservation Service approach (Dyksterhuis 1949) has improved from mid-fair to high-good during the 24 year period with $70 \%$ of the climax vegetation remaining (Tembo 1990).

The grazing history of the BLM range is unknown from 1950 to 1980 period, but detailed records have been kept since 1981 . Before 1981, the general grazing plan was to remove about $50 \%$ of the perennial grass production using continuous grazing. The stocking rate from the late 1960 's to 1981 was about 42 ha animal unit'. In 1981 to 1990 , the rancher destocked the range to an average rate of 72 ha animal unit ${ }^{-1}$. Poor cattle performance and recognition that the range was deteriorating were the reasons for the voluntary reduction in stocking rate based on interviews with the rancher.

BLM records show heavy use levels of 60 to $80 \%$ for the early 1980's but in the mid 1980's to 1990 use levels were considered to be between 20 and $40 \%$. Range condition in 1982 based on BLM records was low-fair (32\% of climax remaining). In 1990 condition had improved to high-fair with $45 \%$ climax vegetation. The USDA Soil Conservation Service procedure developed by Dyksterhuis (1949) was used for estimates of range condition.

\section{Materials and Methods}

One watering point each was selected on the College Ranch and BLM ranges and both had been in operation for 40-50 years, had a long history of continuous grazing, and were similar in topography. On the BLM range $44 \%$ of the area is within $1.6 \mathrm{~km}$ from water, $38 \%$ is between 1.6 and $3.2 \mathrm{~km}$ from water and $18 \%$ is over $3.2 \mathrm{~km}$ from water. On the College Ranch range $50 \%$ of the area is within $1.6 \mathrm{~km}$ from water, $45 \%$ is between 1.6 and 3.2 $\mathrm{km}$ from water and $5 \%$ is over $3.2 \mathrm{~km}$ from water.

Four transects were randomly selected originating from each watering point center. Two transects were oriented between $0^{\circ}$ and $180^{\circ}$ and the other 2 between $180^{\circ}$ and $360^{\circ}$. Each transect was $1,700 \mathrm{~m}$ long. In October and April (1988-1990), vegetation inside a $0.5 \mathrm{~m}^{2}$ quadrat was clipped to ground level at $50 \mathrm{~m}, 150$ $\mathrm{m}$ and every $200 \mathrm{~m}$ from 300 up to $1,700 \mathrm{~m}$ from the watering point. These distances were used to represent the major zones of potential grazing influences on vegetation. Transects were terminated at $1,700 \mathrm{~m}$ because of changes in range site. The vegetation was hand separated by species in the field and oven dried at a constant temperature of $60^{\circ} \mathrm{C}$. Only plant material produced during the previous growing season was included in standing crop evaluation.

Linear Regression analysis was used to evaluate standing crop data pooled across years (Neter and Wasserman 1974). The dependent variable was standing crop $\left(\mathrm{g} / \mathrm{m}^{2}\right)$ and the independent variable was distance from water $(50,150,400,800,1,300,1,700$ $\mathrm{m})$. Standing crop data were pooled into these categories to improve the precision associated with each estimate. Separate regressions were determined for each range and month for each plant and plant category. Regressions for range and month within each plant and plant category were compared using the procedures of Neter and Wasserman (1974) and tested at the $P<0.05$ level.

\section{Results and Discussion}

Regression analyses showed standing crop $\left(\mathrm{g} / \mathrm{m}^{3}\right)$ was significantly related to distance from water for black grama, mesa 


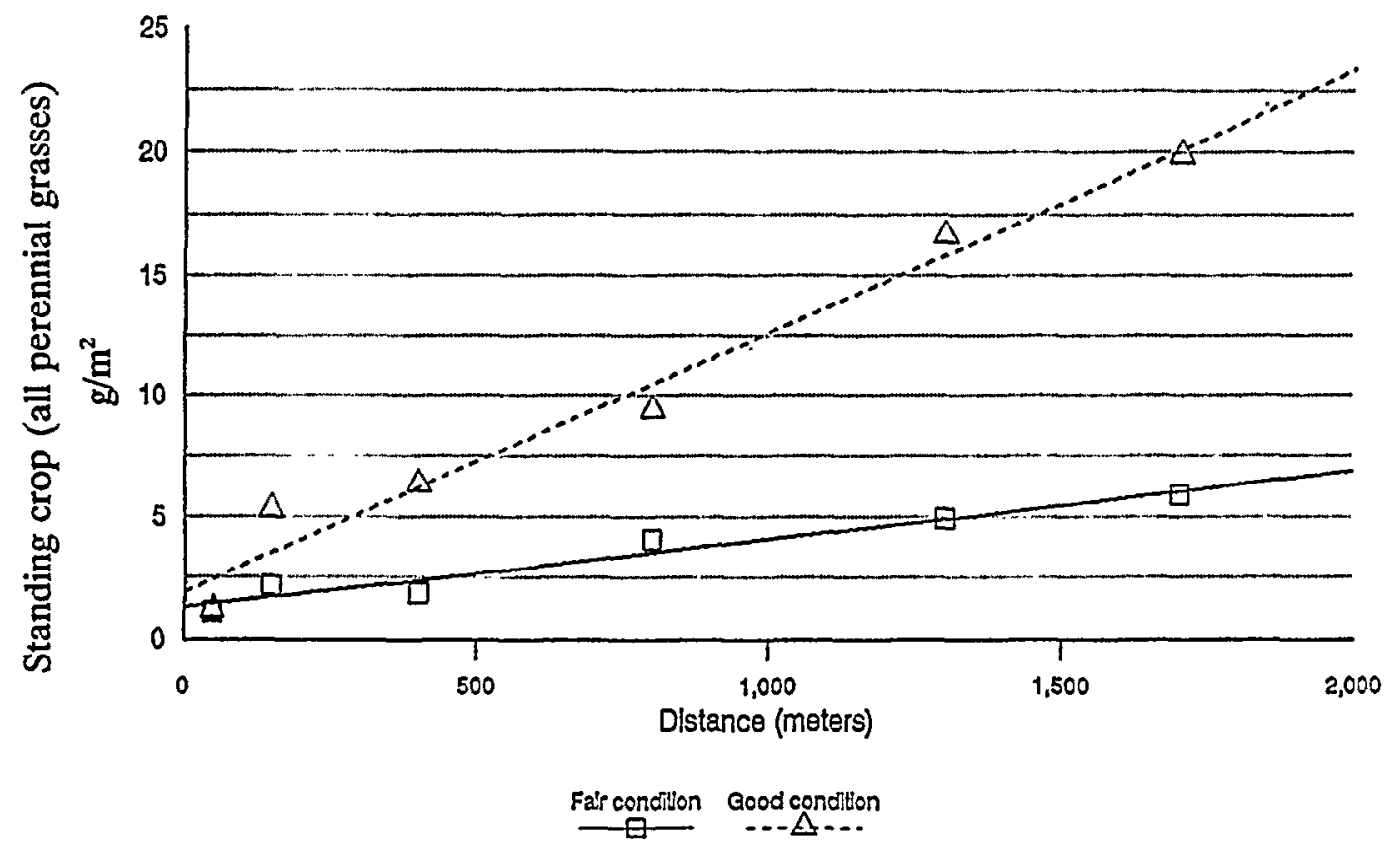

Fig. 1. Standing crop $\left(\mathrm{g}^{2} \mathrm{~m}^{2}\right)$ of all perennial grasses for data pooled across years on good and fair condition Chihuahuan desert ranges at 6 distances from water. (Regression equations are given in Table 2).

dropseed, threeawns, total grasses, poisonous forbs, broom snakeweed, and total poisonous forbs on the good condition range (Tables 1 and 2). However, this association was diminished or lacking for most plant categories on the fair condition range. Regression equations differed between seasons and ranges for the various plant categories with the exception of threeawn on the good condition range in October. Black grama and total grasses on the good condition range showed the highest associations with distance from water. However, black grama were nearly absent from the entire fair condition range, and therefore, showed no association with distance from water.

\section{Perennial Grasses}

Our data show that even long term conservative cattle grazing causes a reduction in perennial grass standing crop as distance from water decreases in the zone $1,700 \mathrm{~m}$ from water (Fig. 1). This effect is accentuated by heavy grazing intensities. Although it has generally been recognized that livestock grazing reduces desirable forage species around watering points (Lange 1969), actual documentation is restricted to Martin and Ward (1970) in Arizona, Foran and Bastin (1984) in Australia, and Soltero et al. (1989) in Mexico. In the Soltero et al. (1989) study the biomass of grasses in the zone under $600 \mathrm{~m}$ from water was reduced about 50 percent compared to the zone $600-1,500 \mathrm{~m}$ from water under a short-duration grazing system. Comparisons of distances between 900 and $1,500 \mathrm{~m}$ from water showed no differences in grass standing crop. Our study confirms that grazing effects are greatly diminished beyond $1,000 \mathrm{~m}$ from water.

Standing crop of the 3 main forage grasses were affected to different degrees by distance from water (Tables 1 an 2). Black grama showed the greatest reduction followed by mesa dropseed and then threeawn. Cattle food habits studies on desert grassland ranges in New Mexico by Rosiere et al. (1975), Hakkila et al. (1987) and Daniel (1991) show black grama to be most preferred followed by mesa dropseed and then threeawn. Black grama is considered to be a decreaser while mesa dropseed and threeawn are considered increasers in terms of grazing response (Soil Conservation Service 1979). Our results confirm this categorization.

Fluffgrass (Erioneuron pulchellum [H. B. K.] Tateoka) is the other important perennial grass found on the study area. It receives little grazing use by cattle (Daniel 1991), and showed no definite trend with distance from water (Fusco 1993). It tended to be more prevalent on the BLM compared to College Ranch range. This grass is highly fibrous and lower in nutritional value compared to the other perennial grasses (Nelson et al. 1970).

On the College Ranch range, forage was scarce (under $10 \mathrm{~g} / \mathrm{m}^{2}$ ) in the zones under $500 \mathrm{~m}$ from water in the fall and under $900 \mathrm{~m}$ from water in the spring. On the BLM range forage was scarce in the zones under $1,700 \mathrm{~m}$ from water in the fall and over the entire study area in spring. Based on these data livestock would have to travel over twice as far between forage and water on the BLM compared to the College Ranch range.

Data on the impact of travel distance between feed and water on cattle performance is limited to Sneva et al. (1973) and Hart et al. (1993). On cold desert range in southeastern Oregon Sneva et al. (1973) found cows trailed $1,600 \mathrm{~m}$ to water in the spring-summer period had calves that gained less weight than those in pastures with water nearby. In the Shortgrass prairic of Wyoming Hart et al. (1993) found calves gained $20 \%$ more on moderately stocked pastures with $1.6 \mathrm{~km}$ maximum distance to water compared to a similarly stocked pasture with a $5.0 \mathrm{~km}$ maximum distance to water. Data from our study show forage on the BLM range was severely depleted in the zone under $1,700 \mathrm{~m}$ from water during the spring (Fusco 1993). In this period cows typically have young calves and are under stress from parturition, lactation and lack of green forage. Failure to adjust stocking rates downward for distance from water could drastically reduce calf 
Table 1. Standing crop of plant species and species groups by distance from water, range condition, and month, 1988-1990.

\begin{tabular}{|c|c|c|c|c|c|c|c|c|c|}
\hline Plant category & $\begin{array}{l}\text { Range } \\
\text { condition }\end{array}$ & Month & 50 & 150 & $\begin{array}{c}400 \\
(300-500) \\
\end{array}$ & $\begin{array}{c}\text { Distance } \mathrm{m} \\
800 \\
(700-900) \\
\end{array}$ & $\begin{array}{c}1300 \\
(1100-1500) \\
\end{array}$ & 1700 & Mean \\
\hline & & & & & & & - standing cro & $\mathrm{d}^{2}$ & - \\
\hline \multirow[t]{4}{*}{ Black grama } & \multirow[t]{2}{*}{ Fair } & April & 0.00 & 0.00 & 0.00 & 0.00 & 0.23 & 0.00 & 0.04 \\
\hline & & October & 0.00 & 0.04 & 0.03 & 0.01 & 0.16 & 0.04 & 0.05 \\
\hline & \multirow[t]{2}{*}{ Good } & April & 0.00 & 0.13 & 0.51 & 2.77 & 5.48 & 8.08 & 2.83 \\
\hline & & October & 0.00 & 0.00 & 2.04 & 2.57 & 8.41 & 12.44 & 4.24 \\
\hline \multirow[t]{4}{*}{ Mesa dropseed } & \multirow[t]{2}{*}{ Fair } & April & 0.27 & 0.32 & 1.36 & 2.35 & $1.9 \mathrm{I}$ & 1.59 & 1.30 \\
\hline & & October & 0.86 & 1.05 & 1.49 & 4.10 & 5.11 & 4.08 & 2.65 \\
\hline & \multirow[t]{2}{*}{ Good } & April & 0.86 & 2.76 & 1.11 & 2.76 & 2.41 & 3.09 & 2.17 \\
\hline & & October & 0.17 & 1.86 & 2.57 & 6.07 & 5.63 & 6.59 & 3.82 \\
\hline \multirow[t]{4}{*}{ Threeawn } & \multirow[t]{2}{*}{ Fair } & April & 0.74 & 1.41 & 0.24 & 0.33 & 0.74 & 0.53 & 0.67 \\
\hline & & October & 1.04 & 1.55 & 0.10 & 0.96 & 0.56 & 1.17 & 0.90 \\
\hline & \multirow[t]{2}{*}{ Good } & April & 0.17 & 2.38 & 2.37 & 2.06 & 5.45 & 4.74 & 2.86 \\
\hline & & October & 0.00 & 2.07 & 3.81 & 2.21 & 5.25 & 3.84 & 2.86 \\
\hline \multirow{4}{*}{$\begin{array}{l}\text { Total perennial } \\
\text { grasses }\end{array}$} & \multirow[t]{2}{*}{ Fair } & April & 1.01 & 1.73 & 1.84 & 2.88 & 2.89 & 2.18 & 2.10 \\
\hline & & October & 1.23 & 2.63 & 1.91 & 5.20 & 6.95 & 9.54 & 4.59 \\
\hline & \multirow[t]{2}{*}{ Good } & April & 1.03 & 5.44 & 3.99 & 7.63 & 13.71 & 16.37 & 8.03 \\
\hline & & October & 1.48 & 5.13 & 8.65 & 11.14 & 19.61 & 24.69 & 11.78 \\
\hline \multirow[t]{4}{*}{ Palatable forbs } & \multirow[t]{2}{*}{ Fair } & April & 0.04 & 0.13 & 0.10 & 0.16 & 0.24 & 0.01 & 0.11 \\
\hline & & October & 0.24 & 0.50 & 0.89 & 0.63 & 0.41 & 0.21 & 0.48 \\
\hline & \multirow[t]{2}{*}{ Good } & April & 0.48 & 2.21 & 2.07 & 1.84 & 1.56 & 0.76 & 1.49 \\
\hline & & October & 0.50 & 1.14 & 2.38 & 3.34 & 1.99 & 1.31 & 1.78 \\
\hline \multirow[t]{4}{*}{ Poisonous forbs } & \multirow[t]{2}{*}{ Fair } & April & 0.10 & 0.06 & 0.15 & 2.09 & 0.07 & 0.03 & 0.42 \\
\hline & & October & 1.11 & 1.42 & 0.70 & 0.30 & 1.11 & 0.80 & 0.79 \\
\hline & \multirow[t]{2}{*}{ Good } & April & 1.32 & 0.22 & 0.22 & 0.39 & 0.05 & 0.02 & 0.37 \\
\hline & & October & 4.17 & 3.39 & 0.13 & 2.70 & 0.28 & 0.31 & 1.91 \\
\hline \multirow[t]{4}{*}{ Broom snakeweed } & \multirow[t]{2}{*}{ Fair } & April & 9.31 & 8.59 & 10.76 & 8.29 & 9.53 & 6.95 & 8.91 \\
\hline & & October & 18.11 & 10.63 & 15.84 & 10.69 & 10.04 & 9.74 & 12.51 \\
\hline & \multirow[t]{2}{*}{ Good } & April & 6.16 & 2.03 & 5.83 & 7.99 & 4.46 & 3.55 & 5.00 \\
\hline & & October & 8.57 & 4.52 & 8.92 & 7.73 & 10.63 & 6.24 & 7.72 \\
\hline \multirow{4}{*}{$\begin{array}{l}\text { Total poisonous } \\
\text { plants }\end{array}$} & \multirow[t]{2}{*}{ Fair } & April & 9.41 & 8.65 & 10.91 & 10.38 & 9.60 & $6.9 \mathrm{~s}$ & 9.32 \\
\hline & & October & 19.22 & 12.05 & 16.54 & 10.99 & 11.15 & 9.82 & 13.30 \\
\hline & \multirow[t]{2}{*}{ Good } & April & 7.48 & 2.25 & 6.05 & 8.38 & 4.51 & 3.57 & 5.37 \\
\hline & & October & 12.74 & 8.11 & 9.05 & 10.43 & 10.91 & 6.55 & 9.63 \\
\hline
\end{tabular}

performance particularly on ranges in fair or poor condition. Holechek (1988) recommends no stocking rate reductions for the zone under $1,600 \mathrm{~m}$ from water, a $50 \%$ reduction for the zone 1,600 to $3,200 \mathrm{~m}$ from water and that the zone over $3,200 \mathrm{~m}$ from water be considered ungrazable. These recommendations seem reasonable based on our study.

Research is needed in the Chihuahuan desert to evaluate how travel distance between water and forage affect cow-calf performance particularly in the spring-early summer stress period. It is likely calf performance would be more adversely affected by extended travel to and from water in the Chihuahuan desert than in the cold desert of Oregon. This is because of the higher temperatures and lack of spring green forage in the Chihuahuan desert.

Breed of cattle can affect range use and productivity. Brangus cattle have been superior to Herefords in productivity in the Chihuahuan desert (Winder et al. 1991). This appears to be at least partially explained by more efficient use of the range based on research presently in progress.

\section{Poisonous Plants}

Poisonous plant biomass (broom snakeweed excluded) showed a weak tendency to decline as distance from water increased (Tables 1 and 2). This tendency was more pronounced on the good than on the fair condition range. Broom snakeweed accounted for over $75 \%$ of the biomass of poisonous plants on both ranges. Other important poisonous forbs included redroot pigweed (Amaranthus pubescens [Uline and Bray] RYBO.), silverleaf nightshade (Solanum triflorum Nutt.), and desert senna (Cassia bauhinioides Gray).

Broom snakeweed standing crop averaged about $50 \%$ higher on the BLM range than on the College Ranch range for data pooled across season, years, and distances from water (Fusco 1993). Pieper et al. (1991), on Shortgrass-pinyon juniper range in southcentral New Mexico, found higher levels of broom snakeweed under heavy compared to moderately stocked pastures. Early observers reported broom snakeweed to be found around livestock watering installations and other areas of livestock concentration (Jardine and Forsling 1922, Talbot 1926). However Jameson (1970) argued against the use of snakeweed as an indicator of range condition and suggested climatic factors were primarily responsible for snakeweed invasions. Research by McDaniel (1984) indicates that reductions in herbaceous cover by both drought and grazing followed by fall-spring precipitation favors snakeweed.

Over the 3 years of study, we observed no cattle death losses from poisonous plants on either the BLM or College Ranch ranges. We attribute the lack of death loss from poisonous plants 
Table 2. Regression equations for predicting standing crop (g/m2), (y) plant species an species groups using distance from water (x) as the independent variable.

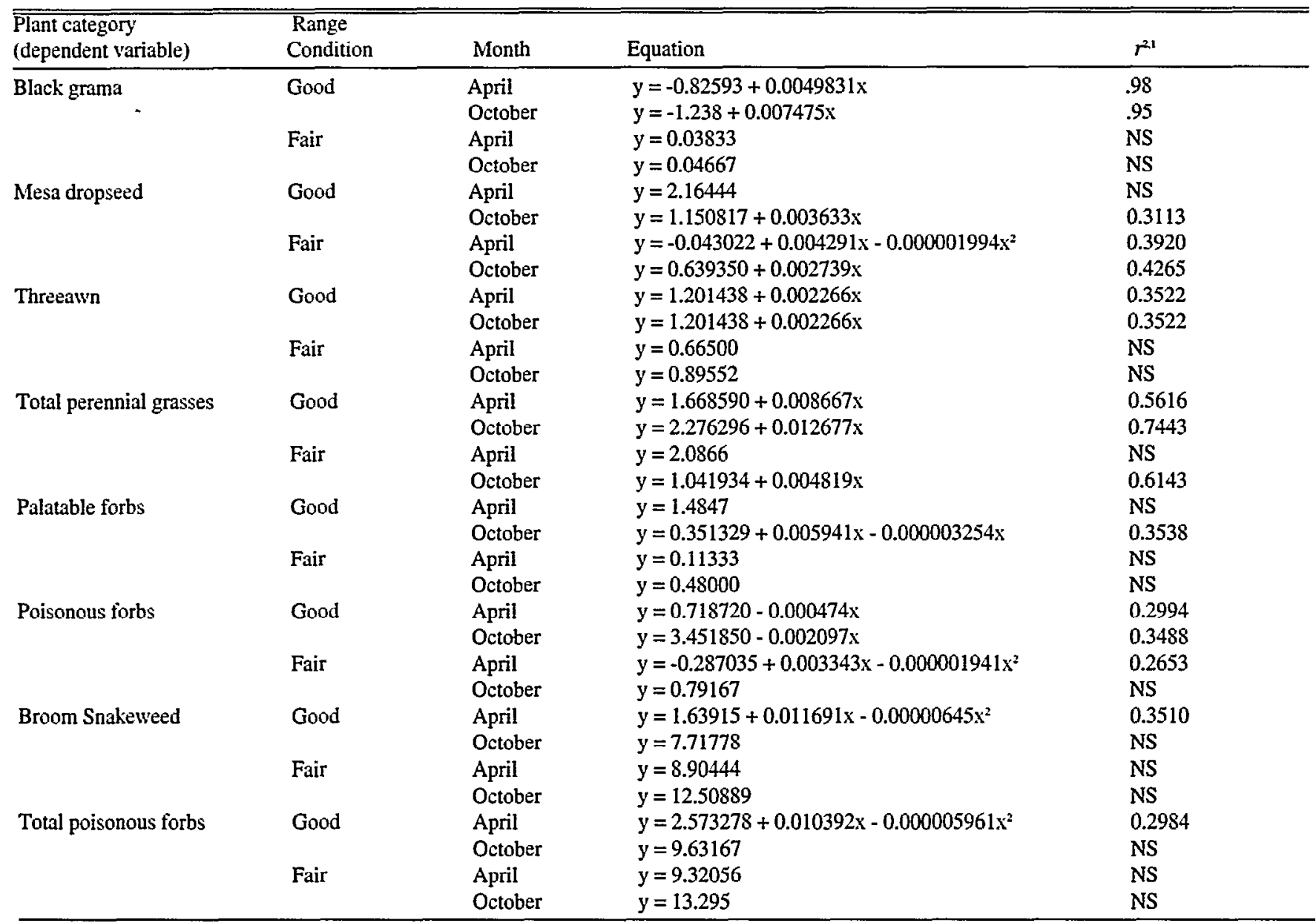

NS = Non-significant at $P<0.05$.

to the conservative stocking rates presently used on the 2 ranges (30-35\% use of perennial grasses). Annual death losses on Chihuahuan desert ranches average about $4 \%$ but on the conservatively stocked College Ranch pastures, annual death losses have been under $1 \%$ for the last 25 years (Holechek 1992). On the adjacent Jornada Experimental Range, Paulsen and Ares (1962) reported cattle death losses averaged $1.74 \%$ between 1939 and 1951 on conservatively stocked pastures. With the possible exceptions of larkspur (Delphinium sp.) and loco (Astragalus $\mathrm{sp}$ ) elevated death losses of livestock (over $2 \%$ annually) from poisonous plants appears to be primarily a stocking rate problem. Long term stocking rate studies by Hutchings and Stewart (1953) in the salt desert of Utah, Klipple and Costello (1960) in the Shortgrass prairie of Colorado, and Taylor and Ralphs (1992) on chaparral range in Texas show heavy stocking rates greatly elevated livestock death losses compared to moderate stocking rates. During a three year study involving 400 head of cattle on several pastures on mountain range in northeastern Oregon, Holechek (1980) noted a death loss of only one animal, and it was not certain the animal died from poisonous plant consumption. These ranges were in high ecological condition and all pastures were conservatively stocked. Annual death losses on the Fort Stanton Experimental range in southcentral New Mexico have been under
$2 \%$ over the last 20 years.

\section{Wildlife Plants}

Russian Thistle, redroot pigweed and broom snakeweed are primary foods for scaled quail, an important gamebird on the study area (Schemnitz 1961, Davis et al. 1975). Redroot pigweed is a key food plant for mourning doves in the Chihuahuan desert (Davis and Anderson 1973). Russian thistle and redroot pigweed were more prevalent crop in the zone under $500 \mathrm{~m}$ from water compared to the zones farther away (Fusco 1993). Highest numbers of mourning doves occur around degraded watering points where redroot pigweed is prevalent (Holechek and Saiwana 1991). Both scaled quail and mourning doves are important gamebirds in southcentral New Mexico and considerable money is spent in hunting related activities involving them. The development of watering points for livestock and the associated vegetation changes around these areas appears to benefit both scaled quail and mourning doves (Holechek and Saiwana 1991). Research is in progress to evaluate how watering points influence pronghorn foods and range use.

\section{Management Implications}

Our study shows that long term conservative continuous cattle 
grazing on upland sandy sites in the Chihuahuan desert severely reduces the biomass of perennial forage grasses in the zone less than $1,000 \mathrm{~m}$ from water. This effect is accentuated by heavier grazing intensities. Poisonous plants and annual forbs dominate the zone under $500 \mathrm{~m}$ from water. Many of these plants are reported to be important foods for scaled quail and mourning doves which are the two primary upland gamebirds in New Mexico. Therefore, from a multiple use standpoint, the vegetation changes caused by conservative livestock ga azing around watering points may have some advantages.

Two practical approaches are available to minimize degradation and enhance productivity of perennial grasses around desert watering points. These involve adjustment of stocking rate for distance from water and rotation of access to watering points. So far there has been a reluctance by both public and private land managers to adopt these practices on Chihuahuan desert ranges.

Reducing stocking rate when distances exceed $1,600 \mathrm{~m}$ from water has long been advocated by range researchers (Valentine 1947). This appears to have benefits for both vegetation (Holechek and Pieper 1992) and livestock (Sneva et al. 1973, Hart et al. 1993). For cattle Holechek (1988) suggested no reduction for the zone under $1,600 \mathrm{~m}$ from water, a $50 \%$ reduction for the zone 1,600 to $3,200 \mathrm{~m}$ from water and that the zone over $3,200 \mathrm{~m}$ from water be considered ungrazable.

Our research supports this recommendation. However we believe that information on the influence of travel distance between feed and water on cow-calf and yearling cattle performance in the Chihuahuan desert would be useful in regard to possible refinements.

On Arizona semidesert ranges, Martin and Ward (1970) found regulating access to watering points could be an effective means of increasing perennial grass production, with little extra cost for labor or fence. Compared to continuous grazing, rotating access to watering points nearly doubled the yield of perennial grasses over an eight year period. Most of the improvement occurred within $300 \mathrm{~m}$ of the watering points. This approach appears to be sound for Chihuahuan desert ranges in New Mexico.

No livestock losses to poisonous plants were noted on either range in our study over the 3 year period of investigation. Poisonous plants accounted for over half the standing crop on the Bureau of Land Management range. The conservative stocking rate presently applied to this range during the period of study appears to explain the lack of poisonous plant death losses. Studies from other range types (Klipple and Costello 1960 , Taylor and Ralphs 1992) indicate livestock losses to poisonous plants are more a function of stocking rate than range condition.

\section{Literature Cited}

Beck, R. F. 1978. A grazing system for semi-arid lands. In: Proc., First Int. Rangel. Congr. D. N. Hyder (Ed), Soc. Range Manage., Denver, Colo.

Beck, R. F., and H. E. Kiesling. 1991. Improving range and cattle production on semidesert rangelands. Livestock Res. Briefs. New Mexico Agr. Exp. Sta., Las Cruces., N.M.

Beck, R. F., R. P. McNeely, and H. E. Kiesling. 1987. Seasonal grazing on black grama rangelands. Livestock Res. Briefs. New Mexico Agr. Exp. Sta., Las Cruces., N.M.

Brown, A. L. 1950. Shrub invasion of southern Arizona desert grasslands. J. Range Manage. 3:172-177.

Brown, D. E. 1982. Biotic Communities of the American Southwest.
Desert Plants 4:169-180.

Buffington, L. C., and C. H. Herbel. 1965. Vegetation changes on semidesert grassland range from 1858 to 1963. Ecol. Monog. 35:139164.

Daniel, A. 1991. Influence of range condition on density and diet of black-tailed jackrabbits and diet of cattle in south central New Mexico. Ph.D. Thesis, New Mexico State Univ., Las Cruces., N.M.

Davis, C. A., and M. W. Anderson. 1973. Seasonal food use by mourning doves in the Mesilla Valley, south central New Mexico. New Mexico Agr. Exp. Sta. Bull. 612. Las Cruces., N.M.

Davis, C. A., R. C. Barkley, and W. C. Haussamen. 1975. Scaled quail foods in southeastern New Mexico. J. Wildl. Manage. 39:496-502.

Dick-Peddie, W. A. 1966. Changing vegetation patterns in southem New Mexico. In: New Mexico Geol. Soc., 16th Field Conf. 234-235.

Dyksterhuis, E. J. 1949. Condition and management of rangeland based on quantitative ecology. J. Range Manage. 2:104-115.

Foran, B. D., and G. Bastin. 1984. The dynamics of Mitchell grass rangeland on the Barkly tableland, Northern Territory. Australian Rangel. J. 6:92-97.

Fusco, M. J. 1993. Influence of range condition and watering points on forage production and composition in southcentral New Mexico. Masters Thesis. New Mexico State Univ., Las Cruces., N.M.

Hakkila, M. D., J. L. Holechek, J. D. Wallace, D. M. Anderson, and M. Cardenas. 1987. Diet and forage intake of cattle on desert grassland range. J. Range Manage. 40:339-342.

Hart, R. H., J. Bissio, M. J. Samuel, and J. W. Waggoner, Jr. 1993. Grazing systems, pasture size, and cattle grazing behavior, distribution and gains. J. Range Manage. 46:81-87.

Hart, R. H., K. W. Hepworth, M. A. Smith, and J. W. Waggoner, Jr. 1991. Cattle grazing behavior on a foothill elk winter range in southeastern Wyoming. J. Range Manage. 44:262-267.

Holscher, C. E., and E. J. Woolfolk. 1953. Forage utilization by cattle on Northern Great Plains ranges. USDA Circ. 918., Washington, D.C.

Holechek, J. L. 1980. The effects of vegetation type and grazing system on the performance, diet and intake of yearling cattle. Ph.D. Thesis, Oregon State Univ., Corvallis., Ore.

Holechek, J. L. 1988. An approach for setting the stocking rate. Rangelands 10:10-14.

Holechek, J. L. 1992. Financial benefits of range improvement practices in the Chihuahuan desert. Rangelands 14:279-284.

Holechek, J. L., and R. D. Pieper. 1992. Estimation of stocking rate on New Mexico rangeland. J. Soil and Water Conserv. 47:116-119.

Holechek, J. L., and L. Saiwana. 1991. Effect of range condition on mourning dove populations in south central New Mexico. Livestock Research Briefs and Cattle Growers' Short Course. New Mexico Agr. Exp. Sta., Las Cruces., N.M.

Hutchings, S., and G. Stewart. 1953. Increasing forage yields and sheep production on intermountain winter ranges. USDA Circ. 925. Washington, D.C.

Jameson, D. A. 1970. Value of broom snakeweed as a range condition indicator. J. Range Manage. 23:302-304.

Jardine, J. T., and C. L. Forsling. 1922. Range and cattle management during drought. USDA Bull. 1031.

Klipple, G. E., and D. F. Costello. 1960. Vegetation and cattle responses to different intensities of grazing on shortgrass ranges of the central Great Plains. USDA Tech. Bull. 1216. Washington, D.C.

Knox, J. H., W. E. Watkins, M. Kager, and K. A. Valentine. 1959. Research on the College Ranch. New Mexico Agr. Exp. Bull. 359. Las Cruces., N.M.

Lange, R. T. 1969. The piosphere, sheep track and dung patterns. J. Range Manage. 22:396-400.

Martin, S. C., and D. E. Ward. 1970. Rotating access to water to improve semidesert cattle range near water. J. Range Manage. 23:2226.

McDaniel, K. C. 1984. Snakeweed control with herbicides. New Mexico Agr. Exp. Sta. Bull. 706. Las Cruces., N.M.

Neale, P. E. 1937. Benefits, based on nutritional requirements, from proper stocking of ranges. New Mexico Agr. Exp. Bull. 825. Las Cruces., N.M.

Nelson, A. B., C. H. Herbel, and H. M. Jackson. 1970. Chemical com- 
position of forage species grazed by cattle on an arid New Mexico range. New Mexico Agr. Exp. Sta. Bull. 561. Las Cruces., N.M.

Neter, J., and W. Wasserman. 1974. Applied Linear Statistical Models. Richard D. Irwin, Inc. Homewood, Ill.

Paulsen, H. A., and F. N. Ares. 1962. Grazing values and management of black grama and tobosa grasslands and associated shrub ranges of the Southwest. USDA Forest Serv. Tech. Bull. 1270. Washington, D.C.

Pieper, R. D., and C. H. Herbel. 1982. Herbage dynamics and primary productivity of a desert grassland ecosystem. New Mexico State Univ. Agr. Exp. Stat. Bull. 695., Las Curecs, N.M.

Pieper, R. D., E. E. Parker, G. B. Donart, J. D. Wallace, and J. D. Wright. 1991. Cattle and vegetation response to four-pasture rotation and continuous grazing systems. New Mexico State Agr. Exp. Sta. Bull. 756., Las Cruces, N.M.

Pinchak, W. E., M. A. Smith, R. H. Hart, and J. W. Waggoner, Jr. 1991. Beef cattle distribution on foothill range. J. Range Manage. 44:267-276.

Rosiere, R. E., R. F. Beck, and J. D. Wallace. 1975. Cattle diet on semidesert grassland: botanical composition. J. Range Manage. 28:9496.

Schemnitz, S. D. 1961. Ecology of the scaled quail in the Oklahoma panhandle. Wildl. Monogr. 8:1-47.

Sneva, F. A., L. R. Rittenhouse, and L. Foster. 1973. Stock water restriction and trailing effects on animal gain, water drunk and mineral consumption. Water-Animal Relations Symp. Proc. 1:34-38.
Soil Conservation Service. 1979. Range site descriptions for New Mexico. USDA NM MLRA 42-15-N.

Soltero, S., F. C. Bryant, and A. Melgoza. 1989. Standing crop patterns under short duration grazing in northern Mexico. J. Range Manage. 42:20-22.

Steel, R. G. D., and J. H. Torrie. 1980. Principles and Procedures of Statistics. McGraw-Hill Book Co., New York, NY.

Talbot, M. W. 1926. Indicators of southwestern range conditions. USDA Farmers Bull. 1782.

Taylor, C. A., Jr., and M. H. Ralphs. 1992. Reducing livestock losses from poisonous plants through grazing management. J. Range Manage. 45:9-13.

Tembo, A. 1990. Influence of watering points and range condition on vegetation of the Chihuahuan Desert. Ph.D. Diss., New Mexico State Univ., Las Cruces., N.M.

Valentine, K. A. 1947. Distance from water as a factor in grazing capacity of rangelands. J. Forest. 45:749-454.

Winder, J. A., B. J. Rankin, and C. C. Bailey. 1991. Maternal performance of hereford, Brangus and reciprocal crossbred cows under semidesert conditions. Livestock Res. Briefs. New Mexico Agr. Exp. Sta., Las Cruces., N.M. 